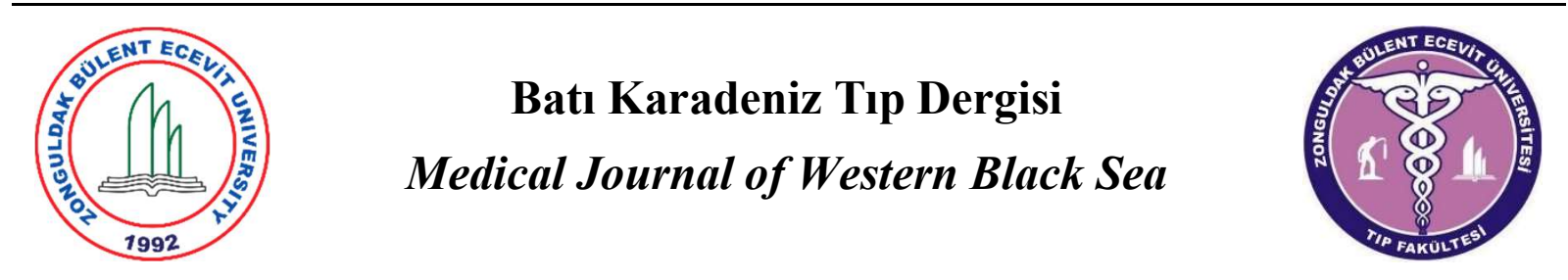

Araştırma Makalesi

Doi: $10.29058 /$ mjwbs.2018.3.3

\title{
Pelvik Kitlelerin Malignite Riski Değerlendirilmesinde Kanser Antijeni 125 (Ca 125), Human Epididymis Protein 4 (HE4), Soluble mesothelin-related protein (SMRP) ve Folat Reseptör Alfa (FOLR $\alpha)$ Ölçümünün Yeri
}

Rabia Başer Açıkgöz ${ }^{a}$, Müge Harma ${ }^{\text {b }}$

${ }^{a}$ Kadın Hastalıkları ve Doğum Kliniği Alaplı İlçe Devlet Hastanesi, Zonguldak, Türkiye

b Jinekolojik Onkoloji Bilim Dalı, Tıp Fakültesi, Bülent Ecevit Üniversitesi, Zonguldak, Türkiye.

ORCİD : Rabia Başer Açıkgöz 0000-0002-2042-0307, Müge Harma 0000-0002-4327-674X

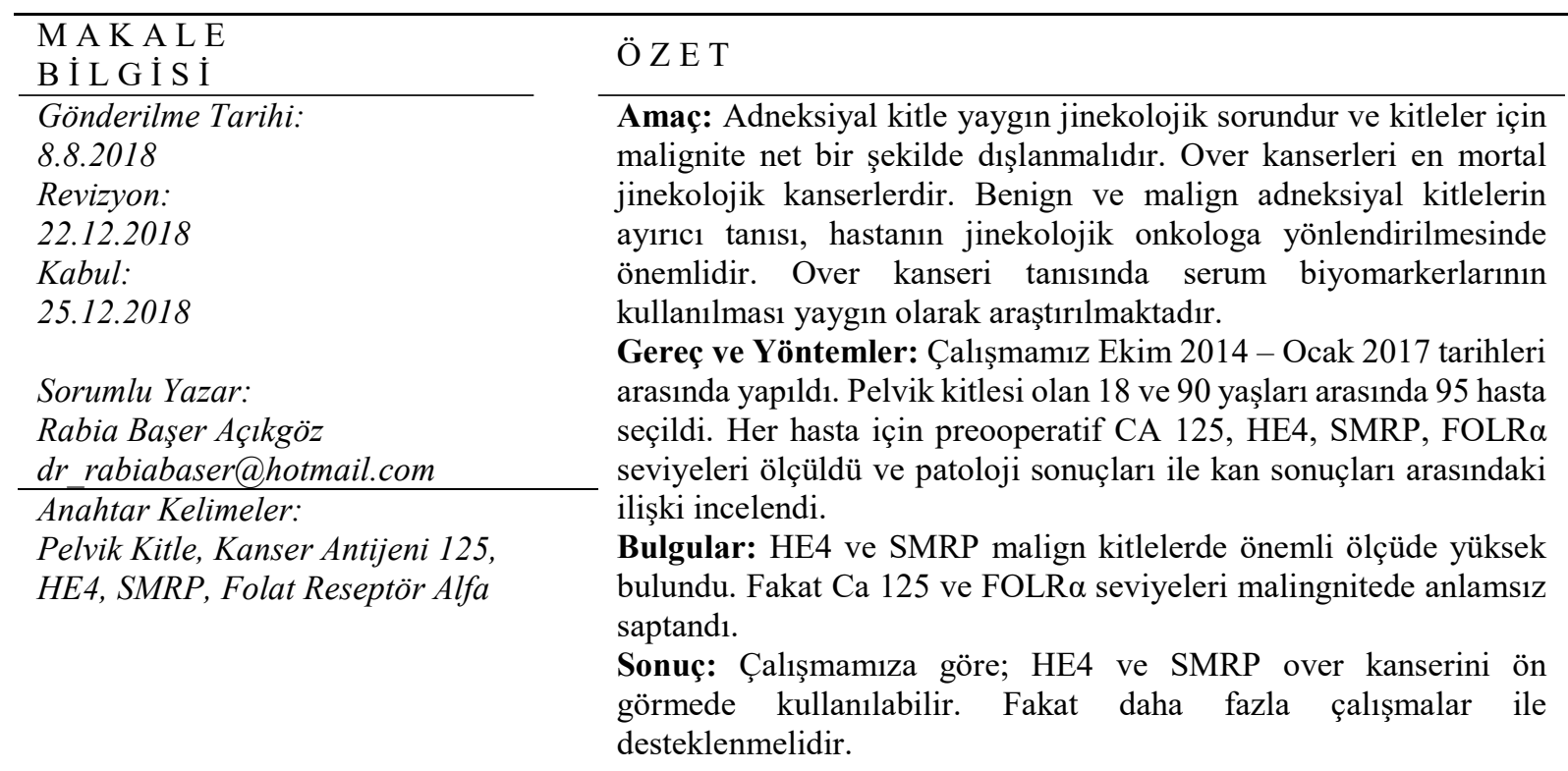




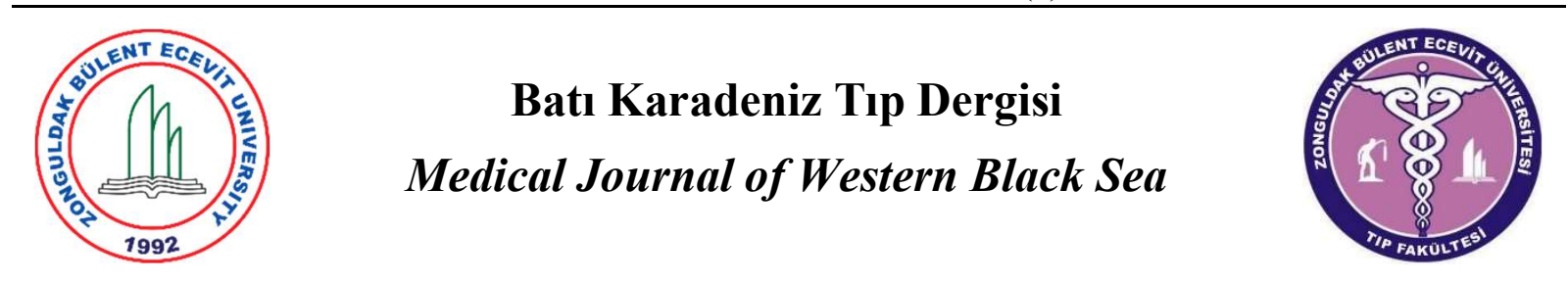

Research Article

Doi: $10.29058 / \mathrm{mjwbs} .2018 .3 .3$

\section{The Role of Cancer Antigen 125 (Ca 125), Human Epididymis Protein 4 (HE4), Soluble Mezotelin Related Protein (SMRP), Folate Receptor Alpha (FOLR $\alpha$ ) in Estimation of Malignancy Risk in Pelvic Masses}

Rabia Başer Açıkgöz ${ }^{\text {a }}$, Müge Harma ${ }^{\text {b }}$

${ }^{a}$ Alaplı State Hospital, Department of Obstetrics and Gynaecology, Zonguldak, Turkey

${ }^{\mathrm{b}}$ Department of Gynecologic Oncology, Faculty of Medicine, University of Bulent Ecevit, Zonguldak, Turkey

A R T I C L E

I N F O R M A T I O N

Date of Submission

8.8.2018

Revision:

22.12.2018

Accepted:

25.12.2018

Correspondence Author: Rabia Başer Açıkgöz dr_rabiabaser@hotmail.com

Key Words:

Pelvic Mass, Ca 125 Antigen, HE4 protein, SMRP protein, Folate

Receptor alpha

\section{A B S T R A C T}

Aim: An adnexal mass is a common gynecologic problem and malignancy must be excluded for any mass that is not clearly benign. Since ovarian cancer is the most common cause of gynecologic cancer death. The differential diagnosis of benign and malignant neoplastic masses is important for referring the patient to the gynecologic oncologist. Use of serum biomarkers for the diagnosis of ovarian cancer is an active area of investigation.

Material and Methods: Our research was performed between September 2014 and January 2017. Between 18 and 90 ages, 95 operated patients because of pelvic masses are included. Preoperatively CA 125, HE4, SMRP, FOLR $\alpha$ levels are measured for each patient and relationship between tumor marker levels and pathological reports is examined.

Results: HE4 and SMRP levels are found higher in malignant masses significantly. But CA 125 and FOLR $\alpha$ levels are not related with malignancy.

Conclusion: HE4 and SMRP can be used as a serum biomarker for prediction of ovarian cancer according to our study. However the data should be supported with more studies. 


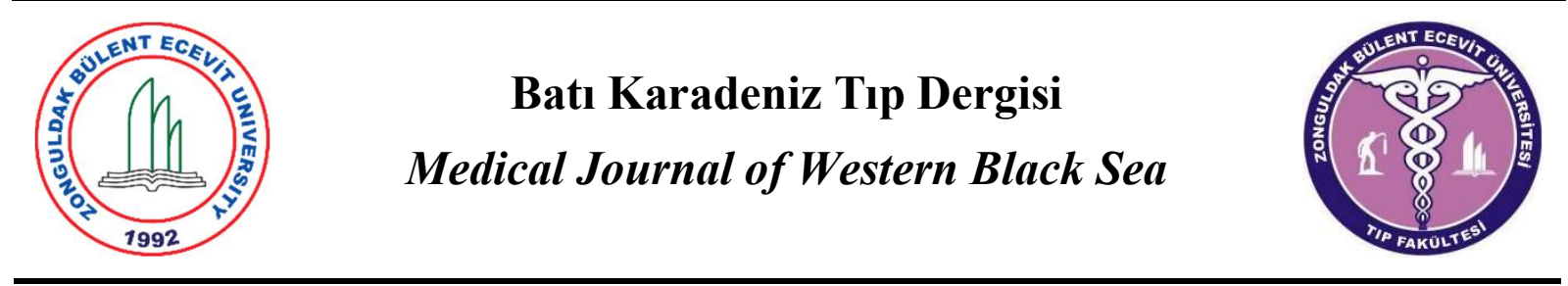

Doi: $10.29058 /$ mjwbs.2018.3.3

\section{Giriş}

Over tümörleri kadınlardaki tümörlerin \%4‘ünü, jinekolojik malignitelerin ise yaklaşık \%23'ünü oluşturur. Over kanseri kadın genital sistemi kanserlerine bağlı görülen ölümlerin $\% 47$ sinden sorumludur (1). Over kanseri Türkiye'de kadınlarda en sık görülen yedinci kanserdir (2). Tıp alanında son çeyrek asırda meydana gelmiş birçok yenilik ve ilerlemeye rağmen, over kanserlerine bağlı mortalitede aynı oranda azalma olmamıştır. Kadınları etkileyen tüm kanserler arasında, over kanseri beşinci en ölümcül olanıdır (3). Over kanserinin görülmesi 40 yaşından sonra artmaktadır. İnsidansı sırasıyla 40 yaş altında 0.4- 8.9, 60-80 yaş aras1 60 olgu/100000 kadın olmaktadır (4).

Over kanseri için risk faktörleri; aile öyküsü, nulliparite, erken menarş, geç menopoz, beyaz 1rk, ileri yaş gibi nedenlere bağlı olarak multifaktöriyeldir (5). Bu faktörlerden aile öyküsü en önemlisidir ve ailesinde over kanseri olanlarda \%5-7 olarak öngörülmektedir (6). Tanımlanabilen genetik neden bulunamayan vakaların \%90-95'i için risk faktörlerinin çoğu, üreme çağında devamlı olan ovulatuar siklus patternleri ile ilişkilidir. Over kanserini, diğer jinekolojik kanserlerden ayıran özellikli belirti ve bulguları olmadığı için, bu hastaların yarısından fazlası ileri evrede tanı almaktadır (7). Yüksek mortalite hastalığın uzun süre belirtisiz seyretmesine bağlıdır. Diğer birçok kanser çeşidinde olduğu gibi erken evrelerde tanı konulabilirse, beklenen yaşam süresinin artacağ1 aşikârdır. Evre 1 de yakalandığında uzun dönem surveyi \%90'lara ulaşmaktadır $(8,9)$. Büyüyen ve yaşlanan bir dünya nüfus yapısını göz önünde tutarak, over kanserlerinin erken tanı ve tedavisinin öneminin bir kat daha arttığını müşahede edebiliriz. Hastalığın prognozu özellikle erken teşhise dayanmaktadır. Her yıl dünyada 204.000 kadın yeni tanı almakta ve bunların yaklaşık 125.000'i bu nedenden dolayı hayatını kaybetmektedir (10). Bu nedenle son zamanlarda erken teşhiste kullanılabilecek tümör belirteçlerine ve görüntüleme yöntemleri araştırmaya başlanmıştır. Çalışmaların çoğunda Human Epididymis Protein 4 (HE4)'ün pelvik kitlesi olan hastalarda en umut vaad eden serum biyomarkırı biyomarkerı olduğu gösterilmiştir (11-16). Yapılan bir çalışmada HE4‘ün ileri evre over kanserlerinde hastalıksız sağkalım için prognostik bir belirteç olduğu saptanmıştır (16).

Çalışmamızda, pelvik kitle nedeni ile opere edilmiş olgularda malign-benign ayrımında kullandığımız tümör belirteçlerinden Kanser Antijeni 125 (CA-125) ve yeni belirteçlerden HE4, Soluble mesothelin-related protein (SMRP), folate receptor 1 (FOLR1)'in pre-operatif dönemdeki etkinliklerini değerlendirmeye çalıştık.

\section{Gereç ve Yöntemler}

Çalışmamıza Bülent Ecevit Üniversitesi Tıp Fakültesi Araştırma ve Uygulama Hastanesine, Jinekolojik onkoloji Polikliniği'ne Eylül 2014- Ocak 2017 tarihleri arasında başvuran ve pelvik kitlesi olan hastalar dâhil edildi. Pelvik kitle tanısı ile laparotomi veya laparoskopi yapılan 18-90 yaş arasındaki, 95 hasta incelendi. Çalışma protokolü için Bülent Ecevit Üniversitesi Tıp Fakültesi Etik Kurulu'na başvuru yapılarak onay alındı.

Kan örneklemesi yapılmadan önce gerekli bilgilendirmeler yapıldı. Aydınlatılmış gönüllü onam formu okutuldu ve yazılı onamları alındı. Jinekolojik tümör hikâyesi olan, sigara kullanan, gebe olan, oral kontraseptif tedavi alan olgular çalışma dışı bırakıldı. Tüm olgulardan geniş bir anamnez değerlendirmesi yapıldı. Geliş şikayeti, yaş, gravida, parite, boy, kilo, vücut kitle indeksi (BMI), ek hastalıkları, geçirilmiş operasyon öyküsü

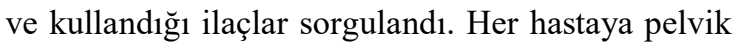
ultrasonografisi yapıldı. Preoperatif ultrasonografi raporları bilgi işlem sistemine kayıt edildi. Pelvik kitle varlığ 1 MR veya BT yöntemleri kullanılarak desteklendi.

Çalışmaya dahil edilen 95 hasta postoperatif histopatolojik değerlendirmeye göre; Benign ve malign ovaryan kitleli olmak üzere 2 gruba ayrıldı. Kan örneği toplama işlemi pre-operatif cerrahi vizit esnasında veya cerrahinin yapılacağı gün sabahında gerçekleştirildi.

CA-125, HE4, SMRP ve FOLR1 seviyesini ölçmek için tüm hastalardan alınan $10 \mathrm{ml}$ kan örneği non-heparinize tüplere toplandi. Santrifüj edilen -80 derecede saklanan numuneler, oda isisina $\left(20-25^{\circ} \mathrm{C}\right)$ gelene kadar bekletildikten sonra çalışıldı. Bu 
çalışmada CA 125, HE4, FOLR1, SMRP serum düzeyleri ELISA yöntemi kullanılarak ölçülmüştür. Hastaların preop ön tanılarına göre kistektomi, ooferektomi, total histerektomi ve salfingooforektomi operasyonlarından biri yapıldı. Malign ön tanısı olanlarda ise standart olan cerrahi prosedür medyan laparatomik insizyon, intraperitoneal organların incelenmesi, sitoloji için ascit ya da yıkama mai alınmas1, periton incelenmesinde şüpheli noktalardan biyopsi alınması, total histerektomi ve salfingooforektomi, omentektomi, appendektomi, pelvik-paraaortik lenfadenektomi uyguland. Tüm hastaların operasyon bilgileri kaydedildi. Spesimenler "frozen section" ve postoperatif histopatolojik sonuçları değerlendirildi. Patoloji sonucu, çalışmamızda altın standart olarak kabul edildi.

\section{Istatistik Analiz}

İstatistiksel değerlendirme SPSS 19.0 (SPSS Inc., Chicago, IL, USA) programı kullanılarak yapıldı. Sayısal değişkenlerin normal dağılıma uygunlukları Shapiro-Wilk testi ile incelendi. Sayısal değişkenler için tanımlayıcı istatistikler aritmetik ortalama \pm standart sapma, kategorik yapıdaki veriler için sayı ve yüzde olarak ifade edildi. Kategorik yapıdaki değişkenler bakımından grupların karşılaştırılmasında Ki-kare testinden faydalanıldı. Sayısal değişkenler bakımından iki grubun karşılaştırılmasında iki ortalama arasındaki farkın önemlilik testi ve Mann-Whitney U testi kullanıldı. En iyi kesim noktalarının belirlenmesi için ROC analizi yapıldı ve tüm değerlendirmelerde $\mathrm{p}<0.05$ değeri anlamlı kabul edildi.

\section{Bulgular}

Çalışmamıza pelvik kitle nedeniyle opere edilen 95 hasta dâhil edilmiştir. Opere edilen bu olgulardan; 68 olgu benign, 22 olgu malign ve 5 olgu borderline olarak rapor edilmiştir. Borderline olgular malign grubunun içerisinde değerlendirilmiştir. Çalışmaya katılan hastaların demografik özellikleri; yaş, gravida, parite ve BMI değerleri bening ve malign grupları arasında karşılaştırılmıştır. Yapılan incelemelerde gruplar arasında, yaş değişkeni istatistiksel olarak anlamlı bulunurken $(p=0.014)$; gravida, parite ve BMI arasında fark saptanmamıştır ( $>0.05)$.

Benign adneksiyal kitleli hastaların histopatolojik tanılarına göre dağılımında en sık rastlanılan benign histopatolojik tanılar; korpus luteum kisti (15 olgu) ve folikül kistidir (13 olgu). Her iki histopatolojik tanı tüm benign histopatolojik tanıların \%40,3 ünü oluşturmaktadır. Malign adneksiyal kitleli olguların histopatolojik tanılarına göre sınıflandırıldığında ise en sık rastlanılan malign histopatolojik tanılar; over endometrioid adenokarsinom (12 olgu) ve seröz adenokarsinom (7 olgu). Her iki histopatolojik tanı tüm malign histopatolojik tanıların \%67,86, sinı oluşturmaktadır.

SMRP ölçümlerine ilişkin Receiver Operating Characteristic (ROC) analizi sonucunda eğri altında kalan alan (AUC) 0.703 (Şekil 1), HE4 ölçümlerine ilişkin yapılan ROC analizinde (AUC) 0.632 olarak saptand1 (Şekil 2) $(\mathrm{p}<0.001)$.

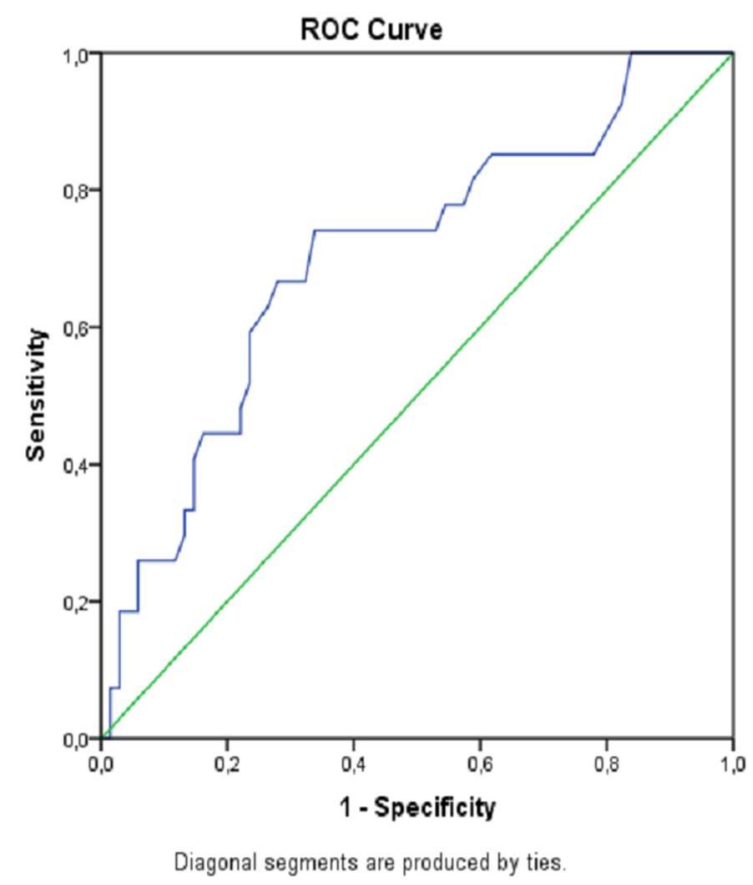

Şekil 1. SMRP için ROC eğrisi

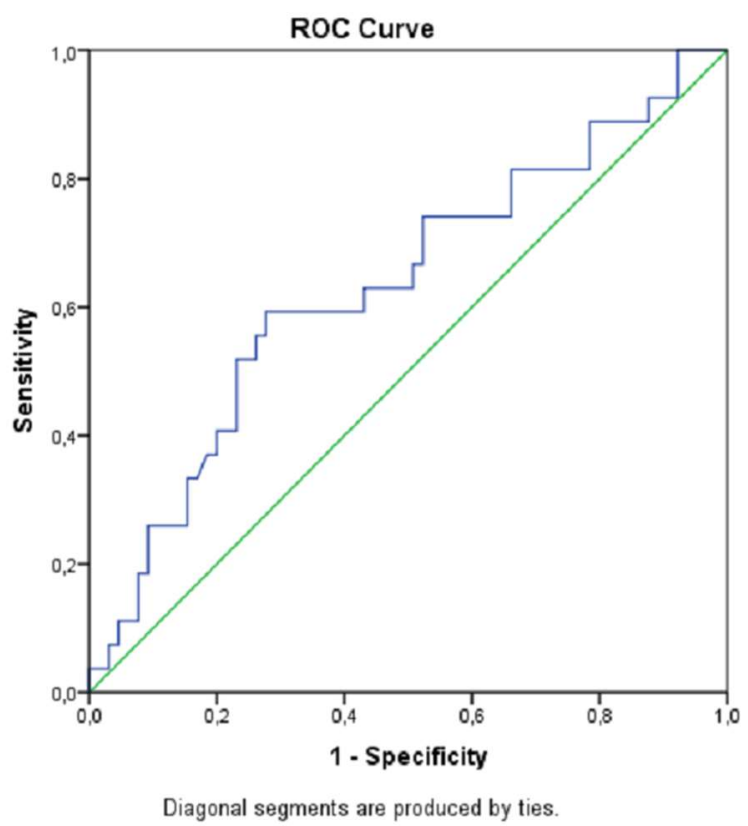

Şekil 2. HE4 için ROC eğrisi 
SMRP için kesim noktası 4.5 pmol/L olarak hesaplanmış olup, duyarlılık \%74.07; seçicilik $\% 66,18$, pozitif kestirim değer $\% 46.5$; negatif kestirim değer \%86.5 olarak hesaplanmaktadır. Kestirim noktası $2668 \mathrm{pg} / \mathrm{ml}$ bulunan HE4'ün duyarlılığ1 \%59.26; seçicilik \%72.31 olarak tespit edildi. Pozitif kestirim değeri \%47.1; negatif kestirim değeri \%81 olarak hesaplanmaktadır (Tablo 1). FOLR1 ölçümleri ile ilişkili ROC eğrisi altında kalan alan (AUC) 0.523, CA-125 için (AUC) 0.625 olarak hesaplandığı için istatistiksel olarak anlamlı saptanmadi.
Literatürde CA-125'in böbrek, akciğer, safra kesesi, mide, pankreas ve kolon hücrelerinde de görülebilen glikoprotein olmas1, CA-125' in overe spesifik bir belirteç olmadığını doğrulamaktadır. Salpenjit, rüptüre ektopik gebelik gibi periton irritasyonu olan olgularda CA-125 kanda artar. Malign over tümörlerinin tanısı, takibi ve nüksünde CA-125' in bir marker olarak kullanılabileceğine dair çalışmalar yapılmıştır (20-22). O'Connel ve arkadaşları 26'sı over kanseri olan 56 vakalık çalışmalarında serum CA-125 için eşik değer 35 $\mathrm{U} / \mathrm{ml}$ alındığında primer over kanserini saptamada

Tablo 1. SMRP veHE4 için ROC analizi sonucu

\begin{tabular}{|c|c|c|c|c|c|c|}
\hline & AUC & $\% 95 \mathrm{Cl}$ & $\begin{array}{c}\text { Kesim } \\
\text { Noktası }\end{array}$ & Seçicilik & Duyarlılık & P değeri \\
\hline $\begin{array}{c}\text { SMRP } \\
\mathrm{pmol} / \mathrm{ml}\end{array}$ & 0.703 & $0.600-0.792$ & $>4.5$ & 66.18 & 74.07 & $<0.001$ \\
\hline $\begin{array}{c}\text { HE4 } \\
\mathrm{pg} / \mathrm{ml}\end{array}$ & 0.632 & $0.525-0.730$ & $>2668$ & 72.3 & 59.2 & 0.0449 \\
\hline
\end{tabular}

\section{Tartıșma}

Ovaryan kitleler jinekolojik muayenede sık görüldüğü için malign-benign ayrımının yapılması; tedavi protokulunu belirlemek ve olası cerrahi girişimlerin ve buna bağlı morbidite ve mortaliteyi azaltması amacıyla kritik öneme sahiptir (17). Over kanserinin, özellikle gelişmiş ülkelerde insidansın artıyor olması, geç evre de mortalitenin yüksek olmas1, erken evrelerde semptomların nadir ve nonspesifik olması nedeniyle, bu hastaların daha iyi seçilebilmesi için gerek görüntüleme yöntemi gerekse biyokimyasal belirteç gibi yeni tanısal yöntemlerin geliştirilmesi gereklilik haline gelmiştir. $\mathrm{Bu}$ çalışmanın amacı pelvik kitle nedeniyle yapılan cerrahilerde preoperatif CA-125, SMRP, HE4, FOLR1'in malign-benign ayırımındaki önemini araştırmaktır. Malign epitelyal over tümörleri yaş ile birlikte görülme sıklığı artar, en yüksek 60-70 yaşlarında (18). Çalışmamızda benign kitle saptanan grup için ortalama yaş $45.62 \pm 16.06$, malign kitle saptanan grup için ortalama yaş $54.26 \pm 12.58$ olarak saptand. Benign kitle saptanan grubun yaş ortalaması malign kitle saptanan gruba göre istatistiksel olarak anlamlı fark saptand $1(p=0.014)$. CA-125; çölemik epitelyum kaynaklı endometrium, endoserviks ve fallop tüplerinde ve mezotel kaynaklı plevra, periton ve perikardial hücrelerde de gösterilmiştir (19). sensitiviteyi $\% 100$, spesifiteyi $\% 43$, pozitif prediktif değeri $\% 60$, negatif prediktif değeri $\% 75$ olarak bulmuşlardır (23).

Pastner ve arkadaşları preoperatif CA-125 yüksekliğini adneksial kitlelerin ayırıcı tanısındaki sensitiviteyi $\% 72$, spesifiteyi $\% 80$, pozitif prediktif değerini $\% 79$ ve negatif prediktif değerini $\% 73$ olarak bulmuşlardır (24). Moore ve ark. 531 pelvik kitlesi olan hastalar üzerinde yaptığı araştırmada, CA-125 eşik değeri $35 \mathrm{U} / \mathrm{ml}$ alındığında duyarlılığ \% 78.3; özgünlüğü \%82; $65 \mathrm{U} / \mathrm{ml}$ olarak alındığında ise duyarlılığı ve özgünlüğü sırasıyla $\% 71.72$ ve $\% 92.5$ olarak izlenmiştir (11). Benign ve malign pelvik kitleli grupları karşılaştırdığımız çalışmamızda CA-125' in medyan değeri 280.4 ve $780 \mathrm{pg} / \mathrm{ml}$ çıkmıştır. Gruplar arasında istatistiksel olarak anlamlı fark saptanmamıştır $(\mathrm{p}=0.058)$.

Mesotelin; mezotelyoma, pankreas, over ve diğer kanser tiplerinde yüksekçe eksprese edilen farklılaşma antijenidir (25). Yaygın kabul edilen over karsinogenezis modeline göre; over kanseri over yüzey epitelinden köken alır, pelvik ve abdominal kaviteye yayılması ardından proteinler belirir, mesotelin gibi proteinler over kanseri erken evre tanısında kullanışlı olabileceği düşünmektedir. Over kanseri SMRP sentezleyen tümörlerden birisidir ve serum SMRP konsantrasyonunu esas alan tanı testi, tanı sürecinde yardımcı olabileceği ile ilişkili yeni çalışmalar yapılmaktadır (26-37). 
Seattle, Fred Hutchinson kanser araştırma merkezinde Dr. Urban ve arkadaşları tarafindan yapılan çift kör çalışmada SMRP'nin over kanser tanısında CA-125'e benzer sensitivite ve spesifitede olduğu ve CA-125 ile SMRP kombinasyonunun tek başlarına kullanımlarına göre daha yüksek sensitivite ve spesifiteye ulaştığı rapor edilmiştir (38). CA- 125 gibi SMRP'nin de benzer yüksek riskli durumlarda (genetik yatkınlık vs.) daha erken tanıyı kolaylaştırabileceğini desteklemektedir.

Anna Fritz-Rdzanek ve arkadaşlarının yaptığı retrospektif çalışmada epitelyal over kanseri (EOC) olan 70 hasta ve 78 sağlıklı kontrol grubu ile karşılaştırılmıştır. Serum biyomarker olarak HE4, SMRP ve CA-125 seviyeleri ölçülmüştür. CA125 'in EOC'de ortalama serum düzeyi $503.55 \pm 560.7 \mathrm{U} / \mathrm{ml}$ iken kontrol grubunda $9.28 \pm 14.47 \mathrm{U} / \mathrm{ml}$ bulunmuştur $(\mathrm{p}<0.001)$. SMRP için bu değer $5.13 \pm 7.64 \mathrm{nM}$ vs. $1.02 \pm 0.89 \mathrm{nM}$ $(\mathrm{p}<0.01)$ ve HE4 için 597.95 \pm 934.59 pM vs. $56.75 \pm 43.79$ pM $(\mathrm{p}<0.001)$ olarak saptanmıştır. EOC'nin klinik evresi ile CA-125, HE4 ve SMRP serum konsantrasyonları arasında pozitif korelesyon saptanmıştır. Seröz olmayan over kanseri tipleri ile karşılaştırıldığında seröz histolojideki epitelyal over kanserlerinde HE4 serum konsentrasyonu arasında anlamlı fark bulunmuştur ( $\mathrm{p}<0.01)$ (39).

Çalışmamızda SMRP ölçümlerine ilişkin ROC analizi sonucunda eğri altında kalan alan (AUC) 0.703 olarak bulunmuştur $(\mathrm{p}<0.001)$. Yani bizim hastalarımız göz önüne alındığında hastanın SMRP için kesim noktası 4,5 pmol/L olarak hesaplanmış olup, duyarlılık \%74.07; seçicilik \%66.18; pozitif kestirim değer $\% 46.5$; negatif kestirim değer \%86.5 olarak bulunmuştur.

Protein yapıda olan HE4, EOC'de fazla salgılandığ1 gösterilmiştir. HE4 reprodüktif sistemden ve üst hava yollarından salgılanır ve serumda saptanabilir. CA-125 gibi ek hastalıklardan etkilenmez (40).

Moore ve ark. 2008'de tümör markerları olarak Her2, CA 72-4, CA-125, aktivin, inhibin, HE4'ün kullanılan çalışmasında, pelvik kitlelerin malignbenign ayırıcı tanısında etkinliğini incelemiş; HE4'ün hem tek başına hem de CA 125 ile birlikte değerlendirildiğinde en yüksek sensitivite ve spesifiteye sahip olduğunu bulmuşlardır. Beklenilenden farklı olarak Evre 1 tümör tespitinde HE4'e CA 125 eklenmesi sensitiviteyi düşürmüştür (41).

HE4'ün CA 125'ten daha anlamlı olduğunu Hellström ve ark 2003'te yaptıkları çalışmada da göstermişlerdir (40). Moore ve ark. 2009 Ocak tarihli yayınlarında HE4 tümör belirtecinin serum düzeylerini benign ve malign adneksiyel kitlelerin ayırımında istatistiksel olarak anlamlı bulmuşlardır $(\mathrm{p}<0.0001)(11)$.

Pelvik kitlesi olan 233 hastada malign-benign ayrımı için yapılmış çalışmada kanda HE4 ve CA125 bakılmıştır. Tek başına CA-125 e göre bu ikilinin malignite riski değerlendirmede sensitiviteyi \%33.1 oranında artırdığ $\left(\% 43.3\right.$ den $\% 76.4^{\prime}$ e) (spesifite her ikisinde de \%95 idi) gösterilmiştir $(11,41)$.

Andersen ve ark. 137 sağlıklı kadın ile 74 Ovaryan kanserli grubu karşılaştırmış olup HE4'ün sensitivite ve spesifitesini sirayla \%71.4, \%94.6 olarak bulmuşlardır (42).

Bizim çalışmamızda, HE4 kan düzeyi benign, malign gruplarda karşılaştırıldığında ortalama değerleri sırasıla 2007.23 ve 2594.88 pg/ml çıkmıştır ve istatistiksel olarak anlamlı saptanmıştır $(\mathrm{p}=0.047)$.

Folat reseptör alfa $(\mathrm{FR} \alpha)$, FOLR1 geni tarafindan kodlanır. FR $\alpha$ over, renal, akciğer ve meme kanserini içeren epitelyal kanserlerde fazlaca eksprese edilen glikozilfosfotidil inositol bağlı proteinidir. Over kanserinde tümör markerları olarak FOLR1 araştırmalarına yol gösterici olmuştur (43). Basal ve arkadaşları Haziran 2009 da yaptığı çalışmada, over kanseri olanlar ile kontrol grubunu karşılaştırarak FR $\alpha$ düzeylerinin erken ve ileri evre hastalar için ayırt edilebilir düzeylerde olduğunu bulmuştur (44). Kimberly ve arkadaşları Ocak 2008'de yaptıkları çalışmada. FR $\alpha$ ekspresyonunun, özellikle rekürren yüksek dereceli, yüksek gradeli seröz tümörlerde sık görüldüğü için metastatik odak ve tekrarlayan tümörler üzerinde korunduğunu ortaya koymakta ve yeni folat hedefli tedavilerin yeni teşhis veya tekrarlayan over kanserinde kullanılabileceği önerilmiştir (45).

FR $\alpha$, çalışmamızda ROC analizinde AUC değeri 0.523 olarak bulunmuştur. İstatiksel olarak anlamsız saptanmıştır $(p=0,7241)$.

Tümör belirteçlerinin ikili veya daha fazla kombinasyonlarının her zaman malign-benign ayrımında tanısal doğruluğu artırmadığı literatürde de görülmüştür. Literatürde, birkaç ulusal geniş sayılı multisentrik çalışmanın dişında, geniş hasta populasyonu içeren çalışmalar sınırlıdır. $\mathrm{Bu}$ durumda kesin yargıya varabilmek yeni birçok çalışmaya ihtiyaç vardır. Çalışmamız da pelvik kitlesi olan 95 olgu değerlendirildiğinde bu sonuçlar bize tıbbı hikâye ve semptomatolojinin yanında SMRP, HE4 kullanımının malign tanısında yardımcı olacağı sonucunu vermiştir. CA-125 ve FR $\alpha$ istatistiksel olarak anlamlı saptanmamıştır ve FR $\alpha$ için kesin yargıya varabilmek için daha fazla çalışmaya ihtiyaç vardır. 
Adneksiyel kitlelerin preoperatif benign-malign ayrımında yapılan çalışmalara rağmen henüz kesin bir tanı yöntemi bulunmamaktadır. En sık kullanılan preoperatif tanı yöntemleri; pelvik muayene, ultrasonografi, tümör belirteci CA 125 iken, yeni çalışmalarda SMRP, HE4 ve FOLR1 özellikle EOC'de ümit vaat etmektedir.

Çalışmamızda, benign grup ile malign grup demografik özellikler açısından karşılaştırıldığında yaş değişkeni istatistiksel olarak anlamlı bulunurken $(\mathrm{p}=0.014)$; gravida, parite ve BMI arasında fark saptanmamıştır $(p>0.05)$. Başvuru semptomlarına göre benign ve malign grupta en s1k karın ve kasık ağrısı şikâyeti saptanmıştır $(\% 38,8$ ve $\% 46,4)$. Bening gruptaki kitlenin (USG, MRI, BT) görüntülemelerine göre $\% 48,5$ kistik olarak izlenirken, malign gruptakilerin \%55,6's1 heterojen olarak görüntülenmiştir. Benign adneksiyal kitleli hastaların histopatolojik tanılarına göre dağılımında en s1k rastlanılan benign histopatolojik tanılar; korpus luteum kisti (15 olgu) ve folikül kistidir (13 olgu). Her iki histopatolojik tanı tüm benign histopatolojik tanıların \%40,3' ünü oluşturmaktadır. Malign adneksiyal kitleli olguların histopatolojik tanılarına göre sinıflandırıldığında ise en sik rastlanılan malign histopatolojik tanılar; over endometrioid adenokarsinom (12 olgu) ve seröz adenokarsinom ( 7 olgu). Her iki histopatolojik tanı tüm malign histopatolojik tanıların \%67,86'sını oluşturmaktadır.

Çalışmamızda SMRP ölçümlerine ilişkin ROC analizi sonucunda eğri altında kalan alan (AUC) 0.703 olarak bulunmuştur $(\mathrm{p}<0.001)$. Tümör belirtecinin ovaryen malignitelere spesifik olması ve erken evrede tanıyıcı olması, çalışmamızda da desteklenmektedir.

Bening malign ayrımında literatür ile benzer olarak HE4 tümör belirtecinin ovaryen malignansilere spesifik olması ve erken evrede tanıyıcı olması, çalışmamızda da bulduğumuz sonuçlarla desteklenmektedir. CA 125'in overe spesifik bir molekül olmayıp pek çok durumda artması, benign malign ayrımını ön görmede yetersizdir. Çalışmamızda da benzer şekilde malignite ön görmede istatiksel olarak anlamsız olarak saptand $1(\mathrm{p}=0,0567)$.

Over kanseri için umut vadeden yeni tümör belirteçlerinden FOLR1, istatiksel olarak anlamsız saptanmıştır $(p=0,7241)$. Ancak FOLR1'in yeni bir tümör belirteci olması nedeniyle daha geniş ve yeni araştırmalara gerek vardır.

\section{Teşekkür}

Çalışmamıza Bülent Ecevit Üniversitesi bilimsel araştırma projelerinin katkısı için teşekkür ederiz.

\section{Kaynaklar}

1. Heintz, A., et al., Carcinoma of the ovary. International Journal of Gynecology \& Obstetrics. 2006;95:161-192.

2. Ferlay, Jacques, et al. Cancer incidence and mortality worldwide: sources, methods and major patterns in GLOBOCAN 2012. International Journal of Cancer. 2015;136(5):359-386.

3. Andersen, M.R., et al. Combining a symptoms index with CA 125 to improve detection of ovarian cancer. Cancer. 2008;113(3): 484-489.

4. Wolk, A., et al., Long-term fatty fish consumption and renal cell carcinoma incidence in women. JAMA. 2006;296(11): 1371-1376.

5. Wentzensen, Nicolas, et al. Ovarian cancer risk factors by histologic subtype: an analysis from the ovarian cancer cohort consortium. Journal of Clinical Oncology. 2016;34(24): 2888-98.

6. Arvas M, Gezer A. Ailevi Over Kanseri, BRCA Genleri ve Over Kanseri Tarama Programlar. Türk Jinekolojik Onkoloji Dergisi. 2004; 7(2): 53-58

7. Goldstein, S.R., Postmenopausal adnexal cysts: how clinical management has evolved. American Journal of Obstetrics and Gynecology. 1996;175(6): 1498-1501.

8. Carlson, K.J., S.J. Skates, and D.E. Singer, Screening for ovarian cancer. Annals of Internal Medicine. 1994;121(2): 124-132.

9. Taylor, K. and P.E. Schwartz, Screening for early ovarian cancer. Radiology. 1994;192(1): 1-10.

10. Sankaranarayanan, R. and J. Ferlay, Worldwide burden of gynaecological cancer: the size of the problem. Research Clinical Obstetrics \& Gynaecology. 2006; 20(2): 207-225.

11. Moore, R.G., et al., A novel multiple marker bioassay utilizing HE4 and CA-125 for the prediction of ovarian cancer in patients with a pelvic mass. Gynecologic Oncology. 2009;112(1): 40-46.

12. Moore, R.G., et al., Comparison of a novel multiple marker assay vs the Risk of Malignancy Index for the prediction of epithelial ovarian cancer in patients with a pelvic mass. American Journal of Obstetrics and Gynecology. 2010; 203(3): 228-228. 
13. Van Gorp, T., et al., HE4 and CA-125 as a diagnostic test in ovarian cancer: prospective validation of the Risk of Ovarian Malignancy Algorithm. British Journal of Cancer. 2011; 104(5):863-870.

14. Montagnana, M., et al., The ROMA (Risk of Ovarian Malignancy Algorithm) for estimating the risk of epithelial ovarian cancer in women presenting with pelvic mass: is it really useful? Clinical Chemistry and Laboratory Medicine. 2011;49(3): 521-525.

15. Kim, Y.M., et al., Evaluation of the accuracy of serum human epididymis protein 4 in combination with CA-125 for detecting ovarian cancer: a prospective case-control study in a Korean population. Clinical Chemistry and Laboratory Medicine. 2011;49(3):527-534.

16. Paek, J., et al., Prognostic significance of human epididymis protein 4 in epithelial ovarian cancer. European Journal of Obstetrics \& Gynecology and Reproductive Biology, 2011. 158(2): p. 338-342.

17. Rottem, S., et al., Classification of ovarian lesions by high-frequency transvaginal sonography. Journal of clinical ultrasound, 1990;18(4): 359-363.

18. Piver, M.S., et al. Epidemiology and etiology of ovarian cancer. In Seminars in Oncology. 1991.

19. Fortner, Renée T., et al. Ovarian cancer early detection by circulating CA 125 in the context of anti-CA 125 autoantibody levels: Results from the EPIC cohort. International Journal of Cancer. 2018;142(7): 1355-1360.

20. Ionescu, Crîngu Antoniu, et al. Correlation of ultrasound features and the Risk of Ovarian Malignancy Algorithm score for different histopathological subtypes of benign adnexal masses. Medicine (Baltimore). 2018;97(31):e11762. doi: 10.1097/MD.0000000000011762.

21. Parashkevova, Asya, et al. Preoperative CA-125 Value as a Predictive Factor for Postoperative Outcome in First Relapse of Platinum-sensitive Serous Ovarian Cancer. Anticancer Research. 2018;38(8): 4865-4870.

22. Zhang, Lei, Ying Chen, and Ke Wang. Comparison of CA125, HE4, and ROMA index for ovarian cancer diagnosis. Current Problems in Cancer. S0147-0272(18)30074-6. doi: 10.1016/j.currproblcancer.2018.06.001.
23. O'connell, G.J., et al., Predictive value of CA 125 for ovarian carcinoma in patients presenting with pelvic masses. Obstetrics \& Gynecology. 1987; 70(6): 930-931.

24. Patsner, B. and W.J. Mann, The value of preoperative serum CA 125 levels in patients with a pelvic mass. American Journal of Obstetrics and Gynecology. 1988;159(4): 873-876.

25. O'Shannessy et al. Serum folate receptor alpha, mesothelin and megakaryocyte potentiating factor in ovarian cancer: association to disease stage and grade and comparison to CA125 and HE4. Journal of Ovarian Research. 2013; 6:29

26. Lowe, K.A., et al., Effects of personal characteristics on serum CA-125, mesothelin, and HE4 levels in healthy postmenopausal women at high-risk for ovarian cancer. Cancer Epidemiology and Prevention Biomarkers. 2008;17(9): 2480-2487.

27. Bast, R.C., Status of tumor markers in ovarian cancer screening. Journal of Clinical Oncology. 2003;21(10): 200-205.

28. Shah, C.A., et al., Influence of ovarian cancer risk status on the diagnostic performance of the serum biomarkers mesothelin, HE4, and CA125.Cancer Epidemiology and Prevention Biomarkers. 2009;18(5): 1365-1372.

29. Chang, K. and I. Pastan, Molecular cloning of mesothelin, a differentiation antigen present on mesothelium, mesotheliomas, and ovarian cancers. Proceedings of the National Academy of Sciences. 1996;93(1): 136-140.

30. Scholler, N., et al., Development of a CA-125mesothelin cell adhesion assay as a screening tool for biologics discovery. Cancer Letters. 2007;247(1): 130-136.

31. Chang, K., et al., Characterization of the antigen (CAK1) recognized by monoclonal antibody $\mathrm{K} 1$ present on ovarian cancers and normal mesothelium. Cancer Research. 1992;52(1): 181-186.

32. Blaustein, A., Peritoneal mesothelium and ovarian surface cells--shared characteristics. International journal of gynecological pathology: official journal of the International Society of Gynecological Pathologists. 1983;3(4): 361-375. 
33. Okamura, H., et al., Structural changes and cell properties of human ovarian surface epithelium in ovarian pathophysiology. Microscopy Research and Technique. 2006;69(6): 469-481.

34. Dubeau, L., The cell of origin of ovarian epithelial tumours. The Lancet Oncology. 2008;9(12): 1191-1197.

35. Okamura, H. and H. Katabuchi, Detailed morphology of human ovarian surface epithelium focusing on its metaplastic and neoplastic capability. Italian Journal of Anatomy and Embryology. 2000;106(2): 263-276.

36. Kurman, R.J. and I.-M. Shih, Pathogenesis of ovarian cancer. Lessons from morphology and molecular biology and their clinical implications. International journal of gynecological pathology: Official Journal of the International Society of Gynecological Pathologists, 2008;27(2):151.

37. McIntosh, M., et al., Combining CA 125 and SMR serum markers for diagnosis and early detection of ovarian carcinoma. Gynecologic Oncology. 2004;95(1): 9-15.

38. Shah CA et.al. Influence of ovarian cancer risk status on the diagnostic performance of the serum biomarkers mesothelin, HE4, and CA125" ) Cancer Epidemiol Biomarkers Prev. 2009;18(5):1365-72

39. Fritz-Rdzanek, A., et al., HE4 protein and SMRP: Potential novel biomarkers in ovarian cancer detection. Oncology Letters, 2012;4(3): 385-389.

40. Hellström, I., et al., The HE4 (WFDC2) protein is a biomarker for ovarian carcinoma. Cancer Research. 2003;63(13): 3695-3700.

41. Moore, R.G., et al., The use of multiple novel tumor biomarkers for the detection of ovarian carcinoma in patients with a pelvic mass. Gynecologic Oncology. 2008;108(2): 402-408.

42. Andersen, M.R., et al., Use of a Symptom Index, CA-125, and HE4 to predict ovarian cancer. Gynecologic Oncology. 2010;116(3): 378-383.

43. Hekman, Marlène $\mathrm{CH}$, et al. Improved intraoperative detection of ovarian cancer by folate receptor alpha targeted dual-modality imaging. Molecular pharmaceutics. 2017;14(10): 3457-3463.

44. Basal, E., et al., Functional folate receptor alpha is elevated in the blood of ovarian. PlosOne. 2009;4(7):62-92
45. Kalli, K.R., et al. Folate receptor alpha as a tumor target in epithelial ovarian cancer. Gynecologic Oncology. 2008;108(3):619-626. 